with the standard and reasonable practice set by the banking community, a task which a depositor is in a singularly poor position to undertake, regardless of the facts of the case. ${ }^{50}$

Perhaps some courts, faced with the Code's provision, might follow the lead of the South Carolina decision, ${ }^{51}$ salvaging in part the stop payment duty by - placing the burden of proof on the bank as to absence of negligence, or by directing the jury's attention to the inferences which arise from a situation when the doctrine of res ipsa loquitur is appropriate. ${ }^{52}$

But even so, it is difficult to understand the inclusion of this provision in the same Article which recognizes the only major flaw in the present stop payment rules, and handsomely corrects its unreasonable harshness on payor banks by allowing subrogation. It would seem more reasonable for the Code to have chosen the course of efficiency and simplicity by making explicit the public policy which for more than a century has defined stop payment as a service to the business community which a bank must perform, if it is to be done at all, because there is no one else who can.

given, (4) that the check was nevertheless paid, and (5) that the money was demanded from the drawee, which demand was refused. 6 Zollman, Banks and Banking \$ 3711 (1936).

The UCC provides specifically only that: "The burden of establishing the fact and amount of loss resulting from the payment of an item contrary to a binding stop order is on the customer." UCC \$4-403(3). The critical question-who bears the burden of proof as to "due care"-is not treated. The usual rule would appear to apply. See note 51 infra.

${ }^{50} \mathrm{~A}$ somewhat comparable situation is that in which a depositor claims loss of property from a bank safe deposit box. In spite of the ease of perjury in the deposit box cases, the courts have often, although not always, ruled that there is a presumption of negligence on the part of the depositary arising from the depositor's testimony that the property was placed in the box and never returned. See e.g., Veihelmann v. Manufacturers' Safe Deposit Co., 303 N.Y. 526, 104 N.E. 2d 888 (1952). The outcome may depend on the form of the depositor's complaint. See Liability for Loss of Contents of Safe-Deposit Box, 133 A.L.R. 279, 291 (1941); Ability of Banks to Limit Liability by Contract, 26 Notre Dame Lawyer 476 (1951).

${ }^{51}$ Carroll v. South Carolina Nat. Bank, 211 S.C. 406, 412, 45 S.E. 2d 729, 731 (1947), where the court said, "[W]e think the admitted facts show a prima facie case of liability and the burden of producing evidence to overcome appellant's prima facie case by showing that it acted in good faith and used all reasonable efforts to comply with the instructions given rested on respondent. ... Appellant would not be expected to know these facts." And see Chicago Savings Bank v. Block, $126 \mathrm{IIl}$. App. 128, (1906). Apparently this rule is followed in Pennsylvania. Thomas v. First Nat. Bank of Scranton, 126 L.I. 203 (Pa., 1952). But the general rule is that the full burden of proof must be sustained by the drawer. 9 C.J.S., Banks and Banking $\$ 411$ (1938).

${ }^{52}$ See Prosser, Torts $\$ \$ 43,44$ (1941).

\title{
DEFAMATION IMMUNITY FOR EXECUTIVE OFFICERS
}

The increasing publicity afforded the workings of government and the current concern over subversive activity ${ }^{1}$ present in an acute form the familiar

\footnotetext{
1 For other examples of the impact of the fear of subversion on traditional areas of the law, see Communists and the Right to Bail, 20 Univ. Chi. L. Rev. 330 (1953); Defamation Immunity, 18 Univ. Chi. L. Rev. 591 (1951).
} 
problems underlying the doctrine of absolute immunity for defamation by executive officers. Matson ข. Margiotti, ${ }^{2}$ a recent Pennsylvania case, is illustrative. Defendant, Pennsylvania's Attorney General, wrote to a district attorney alleging that the latter's assistant, plaintiff, was guilty of "communistic activities,"3 and demanding her discharge. Defendant released the letter to the press prior to mailing it. Upon appeal of plaintiff's libel action the court held defendant absolutely privileged, both in writing the letter and releasing it to the press. A strong dissent was entered by the minority. The case thus illuminates two aspects of the problem: (1) the degree of immunity which attends communications between executive officers of government, and (2) the immunity arising upon the release to the press of such communications.

\section{I}

The absolute immunity ${ }^{4}$ from libel and slander suits ${ }^{5}$ which the law affords certain public officials represents a drastic solution of the conflict between two important interests: the right of the individual to be secure in his reputation and the need of society for the free performance and full disclosure of its business. ${ }^{6}$ Until recently, absolute immunity was confined to legislative, judicial, and sometimes military proceedings, ${ }^{7}$ but has now been generally extended to at least the chief executive officers of the state or nation. ${ }^{8}$

A similar defense, conditional or qualified privilege, is often afforded when absolute immunity is inappropriate. Its protection is much less complete, being

2 Matson v. Margiotti, 371 Pa. 188, 88 A. 2d 892 (1952).

3 Mrs. Matson was subsequently cleared by the Bar Association of Allegheny County of the charges alleged. Ibid., at 193 and 895.

4 "Immunity" and "privilege" are interchangeable terms though their connotations make the former seem preferable. Veeder, Absolute Immunity in Defamation: Judicial Proceedings, 9 Col. L. Rev. 463 (1909).

${ }^{5}$ Privilege, absolute or conditional, covers a wider range of wrong than mere defamation. Whenever private rights are injured by the legitimate performance of public duty a privilege arises. See Standard Nut Margarine Co. v. Mellon, 72 F. 2d 557 (App. D.C., 1934), cert. denied, 293 U.S. 605 (1934) (damage suit for the erroneous imposition of a federal tax); Brown v. Rudolph, 25 F. 2d 540 (App. D.C., 1928) (damage suit for the institution of lunacy proceedings against plaintiff); Spalding v. Vilas, 161 U.S. 483 (1896) (damage suit for interference with contract). Defamation, however, constitutes the largest and most informative area of the privilege's operation.

- Veeder, op. cit. supra note 4.

7 Raymond v. Croll, 233 Mich. 268, 206 N.W. 556 (1925); Hassett v. Carroll, 85 Conn. 23, 81 Atl. 1013 (1911); Peterson v. Steenerson, 113 Minn. 87, 129 N.W. 147 (1910); Newell, Slander and Libel $\$ 351$ (4th ed., 1924); Edwards, Libel-Absolute Privilege-Public Officials, 3 Ga. Bar J., p. 73 (May, 1941); Defamation-Privilege-Extension of Absolute Privilege, 26 Mich. L. Rev. 451 (1928). In this country, legislative immunity is frequently founded on constitutional provisions. Veeder, Absolute Immunity in Defamation: Legislative and Executive Proceedings, 10 Col. L. Rev. 131, 134 (1910). Article I, Section 6 of the United States Constitution provides: "The Senators and Representatives ... shall in all cases, except Treason, Felony and Breach of the Peace, be privileged from Arrest ... and for any Speech or Debate in either House, they shall not be questioned in any other Place." The latter provision confers absolute immunity for any words uttered in debate on the floor of Congress. Cochran v. Couzens, 42 F. 2d 783 (App. D.C., 1930), cert. denied, 282 U.S. 874 (1930).

${ }^{8}$ Rest., Torts $\$ 591$ (1938). 
contingent upon the defendant's good faith in doing the act complained of. ${ }^{9}$ No liability will be imposed when the motive was bona fide, and to determine this a judicial inquiry must be had. ${ }^{10}$ Absolute privilege, however, precludes any inquiry whatever into the propriety of the defendant's motives. Once the privileged occasion is established, malice and bad faith are irrelevant and no redress is given the injured party.11

The policy behind this defense is one of protection from harassment. Were the policy merely one of protection from liability, a conditional privilege would suffice to protect all but those public officials who act in bad faith. But absolute immunity is designed to protect the official from the suit itself, from the expense, publicity, and danger of defending the good faith of his public actions before a jury. ${ }^{12}$ And yet, beyond this lies a deeper purpose, the protection of society's interest in the unfettered discharge of public business and in full public knowledge of the facts and conduct of such business. Absolute immunity is thus a means of removing any inhibition which might deprive the public of the best service of its officers and agencies.

This purpose prescribes the defense's limits. Absolute immunity, requiring the surrender of personal rights for the good of the whole, ${ }^{13}$ should be granted only in cases of necessity. It is the public's good, not the official's, which is the ultimate reason for the rule. Therefore, the privilege should be confined to those officials whose functions are so necessary that individual rights must be subordinated. Society and the individuals who compose it should not be forced to surrender their rights in return for relatively unimportant services. For offices of less than paramount importance a conditional privilege, sustainable in the great majority of cases, is fully adequate.

\section{II}

Since the beginning of the century the defense of absolute immunity has been increasingly afforded to executive offers, ${ }^{14}$ often with dubious results. ${ }^{15}$ The

${ }^{9}$ Ibid., at $\$ 593$.

${ }^{10}$ Ibid., at $\S 619$. "(1) The court determines whether the occasion upon which the defendant published the defamatory matter was privileged. (2) Subject to the control of the court whenever the issue arises, the jury determines whether the defendant did or did not abuse a conditionally privileged occasion."

${ }^{11} 3$ ibid., at p. 223, introductory note.

12 "'The purpose of the law is, not to protect malice or malevolence, but to guard persons acting honestly in the discharge of a public function ... from being harassed by actions imputing to them dishonesty and malice." Veeder, op. cit. supra note 4, at 469.

${ }^{13}$ Newell, op. cit. supra note 7, at $\S 341$.

14 Libel and Slander-Extension of the Doctrine of Absolute Privilege to Inferior Executive and Administrative Officials, 40 Mich. L. Rev. 919 (1942); Libel and Slander-Statutory Extension of the Defense of Absolute Immunity, 11 Fordham L. Rev. 99 (1942); Edwards, op. cit. supra note 7; 26 Mich. L. Rev., op. cit. supra note 7.

${ }^{15}$ E.g., Reagan v. Guardian Life Ins. Co., 140 Tex. 105, 166 S.W. 2d 909 (1942) (defendants filed with the Board of Insurance Commissioners a statement of a third party, forged by its agents, alleging the plaintiff, an ex-employee of defendant, had attempted to collect an insurance premium: held, the statement was absolutely privileged); White v. Holderby, $192 \mathrm{~F}$. 2d 722 (C.A. 5th, 1951) (defendant filed with a Georgia board of education a complaint charg- 
officers first encompassed were of cabinet rank, ${ }^{16}$ the importance of cabinet functions giving a sound basis for the immunity.

Spalding v. Vilas, ${ }^{17}$ a leading American case, was an action against the Postmaster General by a lawyer who held numerous powers of attorney from local postmasters to secure and collect salary adjustments due them by act of Congress. The defendant, forced to act by mandatory legislation secured by the plaintiff, mailed the checks directly to the interested parties and enclosed a letter stating that the attorney's services were unnecessary under the statute. $\mathrm{He}$ stated that a second statute rendered "any transfer of this claim or power of attorney for receiving payment . . . null and void."18 Plaintiff sued for damages incurred in collecting attorney's fees and for injury to his reputation. The Supreme Court held the defendant absolutely immune. His reference of interested parties to statutes concerning their business was within his proper functions. The fact that defendant's interpretation of the second statute was inaccurate, even if maliciously motivated, gave rise to no liability since the interpretation was made and announced in the performance of duty. ${ }^{19}$ Quoting Bradley $v$. Fisher, ${ }^{20}$ the Court distinguished an officer's action wholly without authority and one merely in excess of authority. The former permits of no excuse while the latter is privileged. ${ }^{21}$

The Spalding rule has been widely followed. It is generally felt that officials of at least cabinet rank ${ }^{22}$ should be protected from harassing lawsuits question-

ing in substance the plaintiffs were Negroes and the children should therefore be barred from attending a "white" school: held, that under a Georgia statute this was a proceeding before a court of competent jurisdiction and as such was absolutely privileged).

${ }^{16}$ Ryan v. Wilson, 231 Iowa 33, 300 N.W. 707 (1941); Glass v. Ickes, 117 F. $2 d 273$ (App. D.C., 1940), cert. denied, 311 U.S. 718 (1941); Standard Nut Margarine Co. v. Mellon, 72 F. 2d 557 (App. D.C., 1934), cert. denied, 293 U.S. 605 (1934); Mellon v. Brewer, 18 F. 2d 168 (App. D.C., 1927), cert. denied, 275 U.S. 530 (1927); Spalding v. Vilas, 161 U.S. 483 (1895); Rest., Torts $\$ 591$ (1938); 40 Mich. L. Rev., op. cit. supra note 14; 26 ibid., op. cit. supra note 7.

${ }^{17} 161$ U.S. 483 (1895).

${ }^{18}$ Ibid., at 492.

19 "The act of the head of one of the departments of government in calling the attention of any person having business with such department to a statute relating in any way to such business, cannot be made the foundation of a cause of action against such officers." Ibid., at 493 .

2013 Wall. (U.S.) 335, 350-51 (1871) (an action against a judge for damages sustained by an attorney through the defendant's action in depriving him of his right to practice before the court: held, defendant's action was absolutely privileged).

2t "We are of the opinion that the same general considerations of public policy and convenience which demand for judges . . . immunity from civil suits . . . apply to a large extent to official communications made by heads of Executive Departments when engaged in the discharge of duties imposed upon them by law... . [W] recognize a distinction between action taken ... in reference to matters which are manifestly or palpably beyond his authority, and action having more or less connection with the general matters committed by law to his control or supervision.... [I]f he acts, having authority, his conduct cannot be made the foundation of a suit against him personally for damages, even if the circumstances show that he is not disagreeably impressed by the fact that his action injuriously affects the claims of particular individuals." Spalding v. Vilas, 161 U.S. 483, 498-99 (1895).

22 Federal officers: Glass v. Ickes, 117 F. 2d 273 (App. D.C., 1940), cert. denied, 311 U.S. 718 (1941) (Secretary of the Interior); Standard Nut Margarine Co. v. Mellon, 72 F. 2d 557 (App. D.C., 1934), cert. denied, 293 U.S. 605 (1934) (Secretary of the Treasury); Mellon 
ing their good faith, judgment, discretion, or interpretation of facts. ${ }^{23}$ Whatever dissent exists is largely confined to older and less clear-cut authority. ${ }^{24} \mathrm{But}$ though the Spalding rule originally covered only heads of executive departments, the courts have extended the doctrine to include lower officials. ${ }^{25}$

The first step was to cover the inferior with the immunity of his superior. De Arnaud v. Ainsworth $h^{26}$ involved a libel action on the indirect publication of a report of a bureau chief to the Secretary of War on the claims of a self-professed Civil War hero. The court reasoned that as the defendant was properly investigating and reporting to the Secretary on the plaintiff's claims

the same reason applies for the privilege of the report that would apply if the investigation and report had been made by the Secretary in person. . . . ${ }^{27}$ It is, therefore, not the particular position of the party making the report or communication that entitles it to absolute privilege so much as the occasion ${ }^{28}$ for making it, and the reasons of public policy for the immunity. ${ }^{29}$

A few years later, Farr v. Valentine ${ }^{30}$ gave immunity in his own right to an inferior in his reports to a cabinet officer and, by implication, in his communications to his subordinates as well. The defendant Commissioner of Indian Affairs wrote to the Secretary of the Interior concerning plaintiff's incompetent

v. Brewer, 18 F. 2 d 168 (App. D.C., 1927), cert. denied, 275 U.S. 530 (1927) (Secretary of the Treasury); Spalding v. Vilas, 161 U.S. 483 (1895) (Postmaster General). State officers: Ryan v. Wilson, 231 Iowa 33, 300 N.W. 707 (1941) (Governor of Iowa). Numerous inferior state offcers have been extended absolute privilege; a fair presumption, therefore, is that the top officers of those states are also included. Rest., Torts $\$ 591$ (1938). See also 40 Mich. I. Rev., op. cit. supra note 14; 26 ibid., op. cit. supra note 7.

${ }^{23}$ See Cooper v. O'Connor, 99 F. 2d 135 (App. D.C., 1938), cert. denied, 305 U.S. 642 (1938); Rest., Torts § 591 (1938); Edwards, op. cit. supra note 7.

24 Peterson v. Steenerson, 113 Minn. 87, 129 N.W. 147 (1910) (libel suit against an acting postmaster: in a dictum, the court refused to extend absolute privilege to any but judicial and legislative officers); Maurice v. Worden, $54 \mathrm{Md}$. 233 (1880) (libel suit against a naval officer: dictum that absolute privilege attached only to judicial and legislative proceedings).

${ }_{25}$ This extension has sometimes led to startling results. See, e.g., Donner v. Francis, 255 III. App. 409 (1930) (libelous charges made by a hospital official of the Veterans Bureau against a subordinate held absolutely privileged); Haskell v. Perkins, 165 Ill. App. 144 (1911) (libelous charges by an architect against his superintendent of construction, both being employees of the Board of Education, held absolutely privileged).

2624 App. D.C. 167 (1904), appeal dismissed, 199 U.S. 616 (1905).

27 Ibid., at 177.

28 ' 'Occasion' has long been a word of art used by the courts when dealing with the problem of absolute privilege. It connotes a wider range than the discussion merely of the merits of the central issue." Bigelow v. Brumley, 138 Ohio St. 574, 587, 37 N.E. 2d 584, 591-92 (1941).

In the area of qualified privilege, the term "occasion" covers a much broader sweep of activity than in absolute privilege. For example: "When a communication is fairly made by one in the discharge of a public or private duty, legal, moral, or social, of perfect or imperfect obligation, or in the conduct of his own affairs, to one who has a corresponding interest or duty to receive such communication, the occasion is privileged." International \& G.N.R. Co. v. Edmundson, 222 S.W. 181, 183 (Tex. Comm. App., 1920).

See Goodhart, Defamatory Statements and Privileged Occasions, 56 L.Q. Rev. 262 (1940), for a general discussion of privileged occasion.

${ }^{29} 24$ App. D.C. at 180-81. ${ }^{30} 38$ App. D.C. 413 (1912). 
service in the Bureau. He made similar communications to a subordinate and related the substance of these communications orally to the Secretary. The court granted immunity on libel and slander counts, but remarked that "[h]ad the defendant cornmunicated to one to whom he was under no obligation or duty to report ... a different case would be presented." 31 This development culminated in the assertion of an Illinois court in Donner v. Francis" that "[a]ll communications, either verbal or written, passing between public officers pertaining to their duties and in the conduct of public business are of necessity absolutely privileged." ${ }^{\prime 33}$ No distinction was drawn between communications up or down the hierarchy, reports of consequence or trivia, the remarks of a cabinet officer or those of a secretary to a petty official.

The policy announced in the Spalding case was not intended to afford absolute immunity to a hospital official as in the Donner case nor to a public architect as in Haskell v. Perkins. ${ }^{34}$ The importance of the functions of such officials warrants only a conditional immunity. Nevertheless, state and federal courts alike have extended absolute immunity to public servants lower and lower in the executive hierarchy. ${ }^{35}$ Occasionally, the wisdom of this policy has been questioned ${ }^{36}$ or a refusal to follow it has occurred, ${ }^{37}$ but generally the Donner view has prevailed ${ }^{38}$ even to immunizing in some cases actions of a quasi-public or

al Ibid., at 421.

${ }^{33}$ Ibid., at 412-13.

32255 Ill. App. 409 (1930).

34165 Ill. App. 144 (1911).

${ }^{35} 40$ Mich. L. Rev., op. cit. supra note 14; Fordham L. Rev., op. cit. supra note 14; Edwards, op. cit. supra note 7; 26 Mich. L. Rev., op. cit. supra note 7. The extension, however, has not been solely through the common law. Occasionally, statutes have been interpreted to provide absolute immunity for any proceeding under authority of law. See Libel and SlanderAbsolute Immunity under Statute, 38 Mich. L. Rev. 732 (1940); Fordham L. Rev., op. cit. supra note 14, citing the extension of absolute privilege by statute to communication made "in the proper discharge of official duty" [Calif. Civ. Code (Deering, 1923) §47; Mont. Rev. Code (Choate, 1921) § 5692; N.D. Comp. Laws Ann. (1913) §4354; S.D. Rev. Code (1919) $\S 99]$, the author concludes that, contrary to the principal case of Hughes v. Bizzel, 189 Okla. 472,117 P. 2d 763 (1941), the legislative intent manifested by the word "proper" indicates a grant of only a qualified and not an absolute privilege.

${ }^{36}$ See concurring opinion of Groner, C. J., in Glass v. Ickes, 117 F. 2d 273, 283 (App. D.C., 1940), cert. denied, 311 U.S. 718 (1941).

${ }^{37}$ See, e.g., Peeples v. State, 179 Misc. 272, 38 N.Y.S. $2 d 272$ (S. Ct., 1942), in which the publicly released report of the state audit department contained defamatory matter about the plaintiff, a village police justice. The court held that absolute immunity was not designed to protect all public officers but only those who perform important public services. The report in this case carried a qualified privilege which was sufficient. See also Tanner v. Stevenson, 138 Ky. 578, 128 S.W. 878 (1910); Raymond v. Croll, 233 Mich. 268, 206 N.W. 556 (1925).

${ }^{38}$ In the states: Schlinkert v. Henderson, 331 Mich. 284, 49 N.W. 2d 180 (1951) (letter from member of Liquor Control Commission to Civil Service Commission); Powers v. Vaughn, 212 Mich. 297, 20 N.W. 2d 196 (1945) (report of Department of Health to common council); Hughes v. Bizzel, 189 Okla. 472, 117 P. 2d 763 (1941) (statement of university president to Board of Regents); Layne v. Kirby, 278 Pac. 1046 (Cal. App., 1929), rev'd on other grounds, 208 Cal. 694, 284 Pac. 441 (1930) (letter by subordinate clerk in government engineer's office to his superiors); Stivers v. Allen, 115 Wash. 136, 196 Pac. 663 (1921) (statement of U.S. District Attorney to Secret Service agent); Bolton v. Walker, 197 Mich. 699, 164 N.W. 420 (1917) (statement of an ex-officio member of Board of Estimates to the Board); DeBolt v. McBrien, 96 Neb. 237, 147 N.W. 462 (1914) (letter from state Superintendent of Schools to a 
private nature. ${ }^{39}$ Nor has the doctrine been limited solely to interofficial communications, being sometimes extended to the public reports and activities of officials. ${ }^{40}$

Absolute immunity has also expanded rapidly in the field of quasi-judicial and legislative activity. Relying upon the analogy to established courts and legislatures, the decisions have often found the mere presence of quasi-judicial or legislative power controlling regardless of the public importance of the activities. ${ }^{41} \mathrm{~A}$ more serious departure from sound policy occurs when private or

c ounty superintendent); Haskell v. Perkins, 165 IIl. App. 144 (1911) (report of architect of Board of Education to the Board); Trebilcock v. Anderson, 117 Mich. 39, 75 N.W. 129 (1898) (mayor's veto to council).

In the federal courts: Harwood v. McMurty, 22 F. Supp. 572 (W.D. Ky., 1938) (revenue agent's report to his superiors); United States, to Use of Parravicino v. Brunswick, $69 \mathrm{~F} .2 \mathrm{~d} 383$ (App. D.C., 1934) (consul's report to State Department); Miles v. McGrath, 4 F. Supp. 603 (D. Md., 1933) (report of naval medical officer to his captain); Farr v. Valentine, 38 App. D.C. 413 (1912) (letter from Commissioner of Indian Affairs to Secretary of Interior); De Arnaud v. Ainsworth, 24 App. D.C. 167 (1904), appeal dismissed, 199 U.S. 616 (1904) (report of bureau chief to Secretary of War).

In the courts of England: M. Isaacs and Sons, Ltd. v. Cook, [1925] 2 K.B. 391 (report of High Commissioner of Australia to Prime Minister of Australia); Adams v. Ward, [1917] A.C. 309 (report of Army Council to Parliament and the nation); Chatterton v. Secretary of State for India in Council, [1895] 2 Q.B. 189 (report of the Secretary of State to an undersecretary). In the Chatterton case, the court, at p. 191, quoting a textwriter with approval, said: "For reasons of public policy the same protection [absolute privilege] would, no doubt, be given to anything in the nature of an act of state, e.g., to every communication relating to state matters made by one minister to another, or to the Crown."

${ }^{39}$ See, e.g., Reagan v. Guardian Life Ins. Co., 140 Tex. 105, 166 S.W. $2 d 909$ (1942); White v. Holderby, 192 F. 2d 722 (C.A. 5th, 1951).

${ }^{40}$ Bigelow v. Brumley, 138 Ohio St. 574, 37 N.E. 2d 584 (1941) (libel suit against the author of an officially published argument against a constitutional amendment); Cooper v. O'Connor, 99 F. 2d 135 (App. D.C., 1938), cert. denied, 305 U.S. 642 (1938) (suit for malicious prosecution against Comptroller of Currency for instigating prosecution of plaintiff for violation of banking laws); Brown v. Rudolph, 25 F. 2 d 540 (App. D.C., 1928), cert. denied, 277 U.S. 605 (1928) (suit against the District of Columbia Commissioners for lunacy proceedings previously conducted against plaintiff); Yaselli v. Goff, 12 F. 2 d 396 (C.A. 2d, 1926), aff'd, 275 U.S. 503 (1926) (malicious prosecution by an assistant attorney general against a special assistant to the U.S. Attorney General for suit charging the plaintiff with defrauding the government); Samuelson v. Vinyard, 120 Ore. 197, 251 Pac. 719 (1926) (school board resolution censuring a teacher); Barton v. Rogers, 21 Idaho 609, 123 Pac. 478 (1912) (resolution of the board of trustees libeling a teacher). Contra: Peeples v. State, 179 Misc. 272, 38 N.Y.S. 2d 690 (S. Ct., 1942) (public report of the state department of audit and control).

41 State cases: Pacific Employers Ins. Co. v. Adams, 196 Okla. 597, 168 P. $2 d 105$ (1946) (petition to the state Industrial Commission to reopen an award); Reagan v. Guardian Life Ins. Co., 140 Tex. 105, 166 S.W. 2d 909 (1942) (affidavit filed with the state Board of Insurance Commissioners); Hughes v. Bizzel, 189 Okla. 472, 117 P. 2d 763 (1941) (remarks of university president to Board of Regents about an employee); Roberts v. Pratt, 174 Misc. 585, 21 N.Y.S. 2d 545 (S. Ct., 1940) appeal dismissed, 286 N.Y. 568, 35 N.E. 2d 922 (1941), cert. denied 315 U.S. 613 (1940) (statements made to an assistant attorney general during a pending prosecution); White v. Brinkman, 23 Cal. App. 2d 307, 73 P. 2d 254 (1937) (malicious prosecution by building contractor against building inspector for prosecution under a local building ordinance); Independent Life Ins. Co. v. Rodgers, 165 Tenn. 447, 55 S.W. 2d 767 (1933) (statements to state Insurance Commissioner); Krumin v. Bruknes, 255 Ill. App. 503 (1930) (affidavits filed with Naturalization Bureau); Layne v. Kirby, 278 Pac. 1046 (Cal. App., 1929), 
quasi-public proceedings, institutions, and officers are afforded full immunity for their conduct. ${ }^{42}$ Other courts, however, have held such activity possessed only of a conditional privilege. ${ }^{43}$

Examination of the cases reveals two distinct requirements for the grant of absolute immunity to official communications: (1) the defamatory remarks must have some relevance to the subject matter of the communication, ${ }^{44}$ and (2) the communication must be relevant to the duties of the officer. ${ }^{45}$ The latter conception is summarized in the term "occasion," 46 which implies an obligation or duty

rev'd on other grounds, 208 Cal. 694, 284 Pac. 441 (1930) (letter by subordinate clerk to his superior attacking his chief clerk); McAlister \& Co. v. Jenkins, $214 \mathrm{Ky} .802,284$ S.W. 88 (1926) (statement by Real Estate Commission attacking a real estate company); Samuelson v. Vinyard, 120 Ore. 197, 251 Pac. 719 (1926) (school board resolution censuring a teacher); Bolton v. Walker, 197 Mich. 699, 164 N.W. 420 (1917) (charges of member of Detroit Board of Estimates against a fellow member at a meeting); Larkin v. Noonan, 19 Wis. 82 (1865) (petition to the Governor for removal of a sheriff). Contra: Pecue v. West, 233 N.Y. 316, 135 N.E. 515 (1922).

Federal cases: White v. Holderby, 192 F. 2d 722 (1951) (complaint to Board of Education); Johnson v. Independent Life and Accident Ins. Co. of Jacksonville, Fla., 94 F. Supp. 959 (E.D. S.C., 1951) (letter to Insurance Commissioner giving reasons for the termination of plaintiff's employment); Love v. Snyder, 184 F. 2d 840 (C.A. 4th, 1950) (statements during an appeal before the Civil Service Commission); Smith v. O'Brien, 88 F. 2d 769 (App. D.C., 1937) (statements by Tariff Commission chairman to a job applicant). See also 38 Mich. L. Rev., op. cit. supra note 35 .

12 White v. Holderby, 192 F. 2d 722 (C.A. 5th, 1951) (complaint by an individual to the board of education); Johnson v. Independent Life and Accident Ins. Co. of Jacksonville, Fla., 94 F. Supp. 959 (E.D. S.C., 1951) (letter sent to state Insurance Commissioner); Pacific Employers Ins. Co. v. Adams, 196 Okla. 597, 168 P. 2d 105 (1946) (petition to state Industrial Commission); Reagan v. Guardian Life Ins. Co., 140 Tex. 105, 166 S.W. 2d 909 (1942) (charges against ex-employee filed with the Board of Insurance Commissioners); Sanford v. Foward, 185 Okla. 660, 95 P. 2 d 644 (1939) (report of university president to Board of Regents); Independent Life Ins. Co. v. Rodgers, 165 Tenn. 447, 55 S.W. $2 d 767$ (1933) (statements to state Insurance Commissioner); Krumin v. Bruknes, 255 Ill. App. 503 (1930) (affidavit filed with Naturalization Bureau); Larkin v. Noonan, 19 Wis. 82 (1865) (petition to the Governor for the removal of a sheriff). Contra: Peinhardt v. West, 22 Ala. App. 231, 115 So. 80 (1927), rev'd, $217 \mathrm{Ala} .12,115$ So. 88 (1927) (charges filed by an individual with the mayor and against the chief of police: on reversal, the court held that the charges were only qualifiedly privileged as was the publication of them as official documents).

13 Roberts v. Pratt, 174 Misc. 585, 21 N.Y.S. $2 d 545$ (S. Ct., 1940), appeal dismissed, 286 N.Y. 568, 35 N.E. 2d 922 (1941), cert. denied, 314 U.S. 613 (1940) (charges made against the proprietor of a collecting agency before the local Bar Association and presented to the State Attorney General); Pecue v. West, 233 N.Y. 316, 135 N.E. 515 (1922) (charges made in a letter to the District Attorney; the proceeding was held "not [to be] in substance judicial"); Hassett v. Carroll, 85 Conn. 23, 81 Atl. 1013 (1911) (accusations made by a priest from the pulpit); Bingham v. Gaynor, 203 N.Y. 27, 96 N.E. 84 (1911) (charges against police commissioner filed with mayor).

14 "Of course, when a party steps aside from duty and introduces into his report or communication defamatory matter wholly irrelevant and foreign to the subject of the inquiry the would not be entitled to absolute privilege]." De Arnaud v. Ainsworth, 24 App. D.C. 167, 178 (1904), appeal dismissed, 199 U.S. 616 (1904).

${ }^{45}$ See note 21 supra; Spalding v. Vilas, 161 U.S. 483 (1895); Farr v. Valentine, 38 App. D.C. 413 (1912).

\footnotetext{
${ }^{46}$ See note 28 supra.
} 
upon the communicator to inform another who has a corresponding interest, duty, or obligation to receive the communication. ${ }^{47}$ Thus, if an official communicates to an outsider who has no "right" to be informed, no occasion for the privilege arises and the official bears full responsibility. ${ }^{48}$ Similarly, if, having no obligation himself, an official communicates to one who does have an obligation to receive the communication, the privilege which arises is, at most, no more than that which any private citizen commands in similar circumstances.

The reported cases have mostly concerned vertical communications, i.e., communications within the same executive hierarchy. The question arises whether horizontal communications, i.e, communications between executive hierarchies (as when the Secretary of Labor informs the Secretary of Commerce that one of the latter's employees is incompetent or dishonest), are entitled to absolute or conditional immunity. The Donner case involved a vertical communication, but its language implicitly recognized that an occasion for absolute immunity might arise in horizontal communications. When the requisite obligations exist on both ends of the communication there is no reason why the communication should be less privileged simply because it crossed departmental lines. Such reciprocal obligations will exist less frequently in horizontal than in vertical communications, but where they do exist, it seems inevitable that the privilege will attach. ${ }^{49}$

If the privilege is to be limited at all it should not be in terms of the direction of the communication. Yet a limitation coextensive with the existence of an "occasion" is too broad in that trivial official functions performed maliciously are protected at the expense of individual reputations. The privilege should be limited according to the social importance of the duties of the officer in question. Such a standard is necessarily vague, but it seems the only one pertinent to the policy of the privilege. At least it would alter the result in the more extreme instances of the granting of the privilcge..$^{50}$

17 Bingham v. Gaynor, 203 N.Y. 27, 96 N.E. 84 (1911), where charges by a private citizen filed with the mayor informing him of the police commissioner's incompetence and criminality could claim only a qualified privilege but no absolute privilege.

The severity of the absolute privilege, though limited to public officers, calls for its restriction to the discharge of the proper duties of these men and cannot, therefore, encompass the broad fields of moral or social obligation. Consequently, when an officer steps beyond the pale of such duties, he can claim no more protection than could a private citizen in the same circumstances. Colpoys v. Gates, 118 F. 2d 16 (App. D.C., 1941); Jacobs v. Herlands, 17 N.Y.S. 2d 711 (S. Ct., 1940), aff'd, 259 App. Div. 823, 19 N.Y.S. 2d 770 (1940); Tanner v. Stevenson, 138 Ky. 578, 128 S.W. 878 (1910).

18 E.g., Murray v. Brancato, 290 N.Y. 52,48 N.E. $2 d 257$ (1943), where a judge, in sending a defamatory opinion to an unofficial reporter, acted beyond his judicial function, there being no duty to make such communication.

49 E.g., Schlinkert v. Henderson, 331 Mich. 284, 49 N.W. 2d 180 (1951), where the communication was a letter by a member of the Liquor Control Commission to the Civil Service Commission protesting a reorganization plan for his agency and the proposed employment of the plaintiff.

so See authority cited note 25 supra; White v. Holderby, 192 F. 2d 722 (C.A. 5th, 1951) (board of education); McAlister \& Co. v. Jenkins, 214 Ky. 802, 284 S.W. 88 (1926) (real estate commission). 


\section{III}

Matson v. Margiotti ${ }^{51}$ presents a troublesome illustration of the principles discussed. Defendant Margiotti, Pennsylvania's Attorney General, wrote officially to the District Attorney of Allegheny County complaining of the "communistic activities" of plaintiff, an attorney on the prosecutor's staff. ${ }^{52}$ Margiotti concluded that these activities rendered plaintiff unfit for her position and he demanded her immediate dismissal for the safety of the commonwealth. Before mailing the letter, defendant released it to the newspapers. Twelve days later, defendant again wrote informing the District Attorney of the appointment of a deputy to conduct a public investigation of plaintiff's "alleged communistic leanings, sympathies and utterances." She was to be afforded "every opportunity to be heard with counsel and witness." ${ }^{3} 3$ Plaintiff, however, secured an injunction against the proposed hearing and on appeal, the injunction was unanimously upheld by the Pennsylvania Supreme Court. ${ }^{54}$ The Justice Department,

${ }^{51} 371$ Pa. 188, 88 A. 2 d 892 (1952).

${ }^{52}$ For brevity certain passages are abstracted to indicate the content and tone of defendant's letter:

"As a result of an investigation ... I have ascertained the following facts with regard to Marjory Hanson Matson. ...

" 1 . While ... a student ... she had the reputation among her fellow-students of having Communist tendencies. I am reliably informed that she attended school at the Young Communist League and that she was one of the principal demonstrators against General MacArthur . . . in 1932.

"2. I am informed that Mrs. Matson is on the Executive Board of American-Soviet Friendship and was one of the organizers of the Progressive... Party....

"3. ... Mrs. Matson undertook to act as Counsel for Bernard Salis . . on an appeal from a conviction of Salis for violation of a McKeesport ordinance forbidding the passing out of literature without a permit. The literature ... was signed by the Communist Party of Western Pennsylvania.... She claims she was representing the American Civil Liberties Union in appearing on behalf of Salis.

"4. ... Mrs. Matson sat in the courtroom with counsel, who was defending Nathan Alberts in the Highland Park Riot Case. Alberts is Secretary of the Pittsburgh Branch of the Communist Party....

"5. In the Post Gazette ... the following appears:

'The Pittsburgh Chapter of the American Civil Liberties Union, in a letter to President Truman, has protested the prosecution of 12 leading Communists "for holding beliefs and opinions rather than committing overt acts." "Even in a period of near-hysteria, which this admittedly is, no restrictions should be placed upon the competition of ideas in the marketplace of public opinion," Mrs. Marjory Hanson Matson wrote the President. Mrs. Matson, local A.C.L.U. representative and an assistant district attorney, was careful to point out that her organization bars communists, Bundists and other supporters of dictatorships from serving in its high offices." "

The letter details other similar "communistic activities" of the plaintiff and concludes:

"As Attorney General ... I am writing this letter to demand that Mrs. Matson be dismissed from her position as Assistant District Attorney in Allegheny County, as it appears obvious that her Communistic associations render her unfit to hold this position. Her future retention obstructs justice and becomes dangerous to the security of our people in Pennsylvania." Ibid., at 190-92 and 893-94.

${ }^{53}$ Matson v. Jackson, $368 \mathrm{~Pa} .283,285,83$ A. 2d 134, 135 (1951). As the Pennsylvania Supreme Court said, "it was apparently ... [defendant's] intention to 'try' Mrs. Matson in regard to her loyalty, with a deputy appointed by him to act as "judge." "Ibid.

54 Ibid. 
said the court, may investigate any violation of the law, but here there was no allegation of wrongdoing. To hold otherwise would entitle the Attorney General to conduct hearings as to the political, economic and social views of every public officer in the Commonwealth entrusted with the execution of the laws, from the Governor himself down ... . in order to ascertain whether, in his opinion, they are fit and competent. ... ${ }^{55}$

Nor could the Attorney General's power to supersede local officers provide a basis for the hearings. General qualifications and views are not a basis for supersession..$^{56}$

Plaintiff then instituted the instant case, a libel suit, on the publication of the charges in the first letter. ${ }^{57}$ Defendant demurred, claiming absolute immunity, and was upheld on appeal in a three-to-two decision by the Pennsylvania Supreme Court. ${ }^{58}$ Both the majority and the minority agreed that the letter was libelous per se. The majority, relying on Spalding $v$. Vilas, ${ }^{59}$ stated that the Attorney General has absolute immunity when acting within his official powers but that it "may be abused and lost and ... becomes unavailable if and when the Attorney General ... acts in matters outside his jurisdiction or beyond the scope of his powers and duties." 60 The question then was whether the acts complained of were within his powers. The court felt that although defendant's powers did not extend to investigating plaintiff's general competence, his "wide and vast" powers as chief law enforcement officer enabled him to inform the District Attorney of plaintiff's activities. He could not compel plaintiff's discharge, but he had the right and duty to demand it. The dissent severely criticized the majority's departure from the Jackson case. That decision, the minority said, prescribed the limits to the defendant's official duties. Since he was without legal power to clarify or investigate his charges, a fortiori it was outside his official powers to make them. Having acted beyond his official duties, the most he could claim was a qualified privilege. To characterize his powers as "wide and vast" made him virtually omnipotent.

ss Ibid., at 288 and 136.

${ }^{56}$ Ibid., at 289 and 137.

57 It is interesting to note the alternative grounds upon which the plaintiff could have brought her action. First, there was the possibility of suit upon the second letter in which the defendant announced his intention to hold the hearings. The allegations in the letter were undoubtedly libelous per se, and they were made not to inform the District Attorney of plaintifi's qualifications, which defendant had already done, but to define the proposed hearing. The Pennsylvania Supreme Court had already held that the attempt to hold the hearings was not within defendant's duties or powers. Faving no duty toward the subject of his communication, defendant could claim only a conditional privilege. Second, plaintiff might have sued the newspapers which published the libel. It seems probable that the newspapers had no absolute immunity. See Defamation Immunity, 18 Univ. Chi. L. Rev. 591 (1951).

${ }^{58}$ Matson v. Margiotti, 371 Pa. 188, 88 A. 2d 892 (1952). Defendant had two possible defenses: (1) privilege and (2) truth. He did not plead truth and "his counsel stated at the bar of the Court that a Committee of the Allegheny Bar Association had cleared Mrs. Matson of any charges of Communism." Ibid., at 193 and 895.

59161 U.S. 483 (1895).

${ }^{80}$ Matson v. Margiotti, 371 Pa. 188, 196, 88 A. 2d 892, 896 (1952). 
Applying the rule that both the sender and the recipient of a defamatory communication must bear a legal obligation, duty, or interest in relation to the subject matter of the communication before absolute privilege will attach, it seems clear that here the District Attorney had such a duty or interest in receiving the communication. If the defendant had no corresponding duty, he could claim only a conditional privilege subject to defeasance if the communication was made from improper motives. ${ }^{61}$ In deciding whether such a duty existed, it is noteworthy that defendant could not compel plaintiff's discharge. That indicates that here there was no unbroken line of authority from superior to subordinate, such as exists within a single executive hierarchy. Thus, defendant's duty did not arise from a responsibility and power to hire and discharge. The situation was akin to a horizontal communication between independent departments rather than a vertical communication between superior and subordinate. In such a case, general administrative powers over the field of law enforcement would not seem to provide the legal obligation which the sender of libelous messages must have for absolute immunity to arise. The charge against plaintiff was not one of criminality. The dissent rightly pointed out that by the majority reasoning, "the Attorney General lacks official power to inquire into and investigate what the majority now says he had an official duty to charge." 62

\section{IV}

Even more questionable was the majority's decision that defendant's absolute immunity extended to his release of his letter to the press. A press publication of a libel is far more damaging to reputation than a private communication between officials. Though there is a dearth of authority on this point, some precedent other than the Spalding case and Glass v. Ickes, ${ }^{63}$ cited by the court, does exist. The court might have found support in three cases, ${ }^{64}$ which it did not

61 Perhaps the court was influenced by the severity of the Pennsylvania rule of qualified privilege. The court stated the rule: "defendant in a libel suit who relies upon the defense of conditional privilege has the burden of proving that the communication was published on a conditionally privileged or proper occasion, from proper motive, in a proper manner and was based on reasonable and probable cause." Ibid., at 196 and 896 . Thus, the defendant, once the threshold tort is established, bears the burden of proving not only the "occasion" for the privilege but also those elements of propriety which, in other jurisdictions, are presumptively credited to his cause. Conditional privilege is granted in the first instance because of a decision that defendant's function is socially beneficial and defendant is therefore given the benefit of the doubt. Thus, the policy of granting a conditional privilege is contradictory to the Pennsylvania rule which requires that its pleading be supported by evidence sufficient to sustain any other defense. Yet the harshness of the Pennsylvania rule is not adequate reason to grant defendant absolute immunity in the instant case, for the facts seem to indicate that he deserves no presumption of good faith.

62 Ibid., at 212 and 902.

${ }^{63}$ Glass v. Ickes, 117 F. 2 d 273 (App. D.C., 1940), cert. denied, 311 U.S. 718 (1941).

64 For other cases involving a press publication of libel, see Peeples v. State, 179 Misc. 272, 38 N.Y.S. 2d 690 (Ct. Cl., 1942) (qualified privilege granted to press publication of the official report of the state audit department, based on the public importance of the report); Colpoys v. Gates, 118 F. 2d 16 (App. D.C., 1941) (privilege denied to a U.S. marshal's public explanation 
cite, involving high public officials as defendants. The first, Adams v. Ward, ${ }^{65}$ concerned a release to the press by the defendant, Secretary of the British Army Council, of an official report of that body. The plaintiff, on the floor of Parliament, had accused an army officer of misconduct which had caused the plaintiff's dismissal from the service. The Army Council's report, vindicating the accused officer, reflected upon the plaintiff's character. The House of Lords held that absolute privilege clothed both the report and the press release; the latter on the grounds that the public importance of the issue, calling in question as it did the integrity of the armed forces, warranted publication to the general public of whatever facts might clear the military.

A similar case, Mellon v. Brewer, ${ }^{66}$ arose over the press release by the Secretary of the Treasury of his report to the President. The plaintiff, a special assistant to the Attorney General, had made somewhat discredited charges of irregularities in the issuance of government bonds. The Secretary's report defended his department and impugned the good faith of the plaintiff. In holding the report and its release to the press absolutely privileged, the Supreme Court explained that the plaintiff's charges, undermining public confidence in the fiscal agency, rendered it imperative that the charges be refuted publicly. ${ }^{67}$

In both of these cases, the release to the press was justified because the defendants were publicly defending against charges publicly made. ${ }^{68} \mathrm{Had}$ plaintiff's charges been made only to an interested official, defendants would have had no justification for releasing the defamatory remarks to the press. The "occasion" conferring absolute immunity arose because the public attacks created in the public an interest in receiving the communication by the defendants. Where the interested party is the general public, the press is a proper medium of communication.

In Ryan v. Wilson, ${ }^{69}$ the plaintiff had been Assistant Attorney General of Iowa in an administration prior to that of the defendant, the present Governor.

of his discharge of his deputies); Bingham v. Gaynor, 203 N.Y. 27, 96 N.E. 84 (1911) (privilege denied to press publication of charges against the police commissioner before delivery to mayor; in fact such publication was deemed to have destroyed the qualified privilege adhering to charges).

65 [1917] A.C. 309.

66 18 F. 2d 168 (App. D.C., 1927), cert. denied, 275 U.S. 530 (1927).

${ }^{87}$ 'The court emphasized that the Treasury Department's efficiency and its integrity had been brought under fire, that the confidence of the public in their agency was in danger of being seriously undermined, and that the problem had become one of vital public concern. Therefore, the public had an interest in receiving from the defendant a complete statement of the facts.

${ }^{68}$ This point presents an interesting analogy to the so-called right of self-defense in defamation involving private parties. "The law seems to be well-settled that when one is attacked by defamatory matter published in the press, one may resort to the same methods to reply to or to rebut the charges made." Israel v. Portland News Publishing Co., 152 Ore. 225, 53 P. 2d 529 (1936).

${ }^{69} 231$ Iowa 33, 300 N.W. 707 (1941). 
The defendant released to the press the report of the auditor on the receivership division of the state department of banking. In a minor reference, the report alleged that the plaintiff, while an official, had received a legal fee in a bank receivership. Shortly thereafter, this was discovered to be in error and the defendant promptly acknowledged this to the press. The court held that the defendant had acted within his duty. The report was a public document of general interest and the defendant had a "duty" to give the public whatever information he had by the most effective means available. In this he was absolutely privileged. The court, however, was not wholly convinced by its argument. "[I]f we are wrong in our conclusion that the privilege was absolute, it was certainly a qualified privilege." ${ }^{\prime 70} \mathrm{This}$, in the absence of any indication of malice, was sufficient.

This case differs from the Margiotti situation in that here the defendant released a document by its nature public through the best means of communication, whereas defendant in the Margiotti case released a libelous accusation which it was not his business to make and which the public had no duty to receive. Perhaps a statement of plaintiff's activities would have been proper for such release. A loose charge that plaintiff was communistic was not.

However, the Margiotti court relied upon none of these decisions but upon the Spalding and Ickes cases. In the former, the publication was by letter. The Supreme Court there held that

[t]he act of the head of one of the departments of the government in calling the attention of any person having business with such department to a statute relating in any way to such business, cannot be made the foundation of a cause of action against such

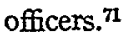

The Ickes case centered on a press release by the Secretary of the Interior addressed to all oil operators warning them against plaintiff's solicitation of funds and stating that he had been barred from practice before the agencies of the department (as were all other ex-employees for a two-year period-a fact the Secretary failed to mention). Relying upon a misinterpretation of the Mellon case, the court said that communications released to the press are generally within the executive powers of a department head, ${ }^{72}$ although there may be circumstances "under which an offcial would exceed his prerogatives in issuing a particular communication to the press." case that

a cabinet officer is within his official right or prerogative, hence absolutely privileged, in informing persons having business with his department of official action affecting such business together with a relevant explanation thereof. ${ }^{74}$

70 Ibid., at 51 and 716.

"1 Spalding v. Vilas, 161 U.S. 483, 493 (1895) (emphasis added).

72 This would seem to be an incorrect interpretation of the Mellon case. The press release there was justified not on pure executive power as this court claims, but upon the vital public interest in the Secretary's report.

73117 F. 2d 273, 277 (App. D.C., 1940), cert. denied, 311 U.S. 718 (1941).

74 Ibid., at 280. 
Applying this rule, the court concluded that Ickes' action was within his official powers. Yet here the publication involved the general public, which had no conceivable interest or duty to receive the communication. A concurring opinion voiced the fear that

in this and previous cases we may have extended the rule beyond the reasons out of which it grew and thus unwittingly created a privilege so extensive as to be unlimited and altogether subversive of the fundamental principle that no man in this country is so high that he is above the law. ${ }^{75}$

Thus, the cases present two rationales for rendering absolutely privileged a cabinet officer's use of the public press. The Mellon and Adams cases recognized that, because of the social importance of the released reports, the interested party was actually the general public and so the press was a proper means of communication. The social importance of the communications in both cases arose from the prior public attacks of the plaintiffs. Without the plaintiffs' accusations and the consequent creation of a public interest, neither communication by the defendants would have possessed the requisite importance to justify release to the press.

The Ickes case sought justification of the press release in the defendant's purpose to inform those dealing with his department of facts important to their relationship. The court ignored the problem of excessive publication. Communication by mail or administrative bulletin would have sufficed to reach such a restricted class of interested recipients and hence defendant should have received only a qualified privilege as to the press release. The Ickes case also suggests, as the concurring opinion indicates, that an executive officer may possess immunity for almost any press release he cares to make. However, this dictum is supported neither by the cases nor by any intelligible policy. Both the Mellon and Adams rule and the Ickes rule, then, are subsumed under the general rule that to be privileged a communication must be directed to those who have an interest in receiving it.

In any event, the Margiotti majority cited the wrong authority for a doubtful proposition. ${ }^{76}$ There was, in the instant case, no immediate and vital public interest in the defendant's reyelation, no public attack by the plaintiff upon the integrity of the government, such as justified publication in the Mellon and Adams cases. Nor was there a pressing need to communicate to vitally interest-

${ }_{75}$ Thid., at 282. See Edwards, op. cit. supra note 7, at 74, for a discussion of this case- 'it is difficult to explain in what respect the Secretary's action [the press release] was in the performance of an afficial [sic] function."

${ }^{70}$ The majority bases its case on the public's right to be informed of the particular acts of its officials. This assertion neither squares with the authorities the court cited, i.e., the Spalding and Ickes cases, nor finds any recognition in other decisions. Its closest support is a dictum in Colpoys v. Gates, 118 F. 2d 16 (App. D.C., 1941), where the court said in refusing relief to a U.S. marshal's public explanation of the discharge of deputies, "Cabinet officers have a political function and public interest is thought to require that they be not restricted by fear of libel suits from publicly explaining their acts and policies." Ibid., at 17. The danger of this doctrine is apparent. No tenable limits are in view and though the general philosophy has much to recommend it, it is not apparent why a qualified privilege is, in reality, insufficient. 
ed, widely dispersed parties via the press, as the Ickes case would have it, which would justify Margiotti in riding roughshod over plaintiff's reputation. Even the slender justification of releasing an essentially public document, as in the Ryan case, was absent here; and the Ryan court was unsure whether the defendant had an absolute or qualified immunity.

Perhaps the closest precedent to the Margiotii situation is found in Jacobs v. Herlands, ${ }^{77}$ a New York case which arose over the disappearance of $\$ 50,000$ from a government bureau. The defendant, apparently a prosecutor or special investigator, called a press conference at which he announced his intention to investigate the plaintiff's bank account in connection with the crime. The court held absolute privilege not available as a defense.

No prosecuting officer or investigator is justified, in anticipation of finding evidence of wrongdoing, in making a public statement to the press which injures the reputation of any person. With due regard for the right of the public to be informed of the conduct of its officials, the time for such information to be given is after evidence of wrongdoing has been obtained. The rights of the individual, as well as the rights of the prublic, are to be considered. ${ }^{78}$

It therefore appears that defendant Margiotti should have been granted only a conditional or qualified immunity. ${ }^{79}$

\section{ConcLusion}

The Margiotli decision wrongly granted absolute immunity both to defendant's letter and to its release to the press. The result conforms in no way to the policy which alone justifies the privilege. The law of absolute immunity for executive communications is muddled; the underlying problems unresolved. The contribution of the Margiolti opinion to their solution is extremely slender.

7717 N.Y.S. 2d 711 (S. Ct., 1940), aff'd, 259 App. Div. 823, 19 N.Y.S. $2 d 770$ (1940).

78 Ibid., at 713 (emphasis added).

${ }^{79}$ If the press had absolute immunity for its printing of defendant's letter on the ground that it is a record libel, it would appear that defendant should possess the same immunity for his publication of the libel to the press. Conceivably, however, one who makes a record libel should be without absolute immunity for publishing it to the press. The opportunities for politically-motivated abuse under the opposite rule are obvious. Another answer is that newspapers probably do not have absolute immunity in printing record libel. See Defamation Immunity, 18 Univ. Chi. L. Rev. 591 (1951). Further, it does not appear that defendant's letter is the sort of official record which newspapers can publish. Unlike record libel in regular judicial, legislative, or executive proceedings, defendant's letter could not have been obtained by the press were it not for defendant's publication to them. Thus, the argument fails that defendant should share the absolute immunity of the press.

\section{LATENT EQUITIES}

Whether the assignee of a chose in action takes the chose subject to "latent equities" has been a debatable issue among scholars for over a century. Ievenbaum v. Hanover Trust Company presents a typical "latent equity" problem.

1253 Mass. 19, 148 N.E. 227 (1925). 